\title{
En mann i 60-årene med forvirring, stivhet og redusert allmenntilstand
}

\author{
En pasient med kjent schizofreni ble henvist til medisinsk avdeling av \\ fastlegen på grunn av uavklart akutt somatisk og psykiatrisk tilstand. \\ Tett samarbeid mellom forskjellige legespesialister var nødvendig for \\ å sikre rask diagnostikk og behandling.
}

En mann i 60-årene med paranoid schizofreni ble av fastlegen akutthenvist til medisinsk avdeling med en ukes sykehistorie med økende forvirring, redusert allmenntilstand og autonome symptomer. I henvisningsskrivet ble det beskrevet en ytterligere forverring de siste to dagene med økende angst og paranoia og med behov for kontinuerlig tilsyn i pasientens omsorgsbolig. Det var vanskelig à medisinere ham fordi man fikk inntrykk av at han ikke forsto verbale instrukser om å ta tabletter. Han var sengeliggende, ga lite kontakt og var stiv i kroppen. Den somatiske undersøkelsen utført av fastlege viste hypertensjon (176/80 mm Hg), takykardi (puls 124 slag/minl og stivhet i bena. Det ble bedt om snarlig psykiatrisk vurdering.

Pasienten ble diagnostisert med paranoid schizofreni i 30-årsalderen. Han ble tidligere behandlet med zuclopenthixol decanoate, som ble seponert for ti år siden grunnet ekstrapyramidale bivirkninger. Preparatet ble erstattet med risperidon depotinjeksjon, som han har fått siden.

Pasienten har en mild psykisk utviklingshemning og blir medikamentelt behandlet for hypertensjon og diabetes mellitus type 2. Han bor i en omsorgsbolig og har i hele sitt voksne liv vært avhengig av tett oppfølging fra helsevesenet. Pasienten har vært i habituell tilstand de siste to årene, uten behov for sykehusinnleggelse. Faste medikamenter er linagliptin $5 \mathrm{mg} / \mathrm{metforminhydroklorid} 1700 \mathrm{mg}$, risperidon depotinjeksjon $50 \mathrm{mg}$ annenhver uke (siste injeksjon dagen før innleggelsen), biperiden $4 \mathrm{mg}$, mirtazapin $15 \mathrm{mg}$, oxazepam $15 \mathrm{mg}$, ibuprofen $800 \mathrm{mg}$, paracetamol $4 \mathrm{~g}$, buprenorfin depotplaster $15 \mu \mathrm{g} / \mathrm{t}$, pantoprazol $40 \mathrm{mg}$, oxazepam $15 \mathrm{mg}$, zopiklon 7,5 mg. Det ble vurdert ikke å være klinisk relevante interaksjoner mellom disse medikamentene.

Ved innkomst ble pasienten undersøkt av turnuslege, med følgende funn: blodtrykk 149/78 mm Hg, puls $115 \mathrm{slag} / \mathrm{min}$, temperatur $38,0^{\circ} \mathrm{C}$ og respirasjonsfrekvens $28 / \mathrm{min}$. Pasienten var generelt rigid i ekstremitetene. Det var utslag på leukocytter og nitritt på urinstiks. Blodprøver viste forhøyede leukocytter, som ble vurdert til å være stressutløst, ellers var det normale parametere (tab 1). Til- standen ble vurdert som en forverring av pasientens kroniske psykotiske lidelse, og han ble overført til akuttpsykiatrisk avdeling.

I innkomstjournalen ble pasienten beskrevet som våken, men ikke orientert for tid, sted eller situasjon. Han var angstpreget og lå anspent $i$ sengen. Siden det ble gjennomført somatisk undersøkelse i mottak, ble dette ikke vurdert som nødvendig på akuttpsykiatrisk avdeling. Miljøterapeutiske tiltak med trygging, skjerming og tett oppfølging ble iverksatt. Pasienten fikk mecillinam for en mistenkt urinveisinfeksjon, ellers ble det ikke foretatt noen endringer $i$ medisineringen. Fra dag to til fire ble pasienten ikke undersøkt av lege. Miljøterapeutene vurderte ham som uendret.

Pasientens nyoppståtte tilstand ble oppfattet som katatoni forårsaket av paranoid schizofreni. Katatoni er et nevropsykiatrisk syndrom karakterisert av motorisk immobilitet som stupor, mutisme og næringsvegring. Det kan utvikles på bakgrunn av psykisk lidelse, hyppigst ved affektiv lidelse, men også ved schizofreni og som ledd i en nevrologisk eller medisinsk tilstand. Malign katatoni er en alvorlig form med feber og autonom instabilitet (1). Symptomer på tilstanden fremgår av tabell $2(1-4)$.

Dag fire hadde pasienten økende symptomer med tiltagende forvirring, mer rigiditet, svetting og dysfagi. Vitale parametere var temperatur $39,7^{\circ} \mathrm{C}$, blodtrykk $154 / 86 \mathrm{~mm} \mathrm{Hg}$ og puls $121 \mathrm{slag} / \mathrm{min}$. Laboratorieprøvene viste blant annet forhøyede leukocytter og kreatinkinase (CK) 730 U/1, mens C-reaktivt protein (CRP) var normalt (tab 1). Grunnet mistanke om malignt nevroleptikasyndrom (MNS) ble alle psykofarmaka seponert og pasienten overflyttet til medisinsk avdeling.

Ved feber og stivhet hos pasienter som bruker antipsykotika er malignt nevroleptikasyndrom, som forekommer hos i underkant av $1 \%$, en viktig differensialdiagnose. Dette er en alvorlig tilstand med ca. $20 \%$ mortalitet (5). Hovedsymptomene er hypertermi, muskulær rigiditet, endret bevissthet og autonom instabilitet i form av takykardi, takypné, svingende blodtrykk, svette og

\author{
Hanne Indermo Solhaug \\ hanne.indermo@gmail.com \\ Rosalie Broekhof \\ Kari Bruheim \\ Sara Germans Selvik \\ Psykiatrisk klinikk \\ Sykehuset Namsos \\ Mathis Heibert \\ Medisinsk klinikk \\ Sykehuset Namsos
}


inkontinens (tab 2) (1, 5). Alvorlig hypertermi og ekstrem rigiditet kan forårsake rabdomyolyse, noe som kan medføre nyresvikt.

Det ble gjort supplerende undersøkelser. CT caput viste ingen fersk patologi, men et eldre infarkt frontalt på høyre side var tilkommet sammenlignet med undersøkelse for ti år siden. Spinalpunksjon viste ikke tegn til infeksjon. På grunn av uttalt rigiditet ble biperiden gjeninnsatt.

Diagnosen malignt nevroleptikasyndrom stilles på grunnlag av det kliniske bildet og laboratorieprøver(nøytrofilleukocytose, forhøyede verdier av levertransaminaser og forhøyet kreatinkinase) (5). Det er en eksklusjonsdiagnose og kan være vanskelig å skille fra en rekke andre tilstander (ramme 1). Anbefalte supplerende undersøkelser er ytterligere laboratorieprøver, bildediagnostikk av hjerne, spinalpunksjon og EEG.

Psykiatriske pasienter blir ofte behandlet med flere psykofarmaka samtidig og har større risiko for å utvikle tilstander som serotonergt syndrom og antikolinergt syndrom (tab 2) (5). Serotonergt syndrom skyldes en overstimulering av serotoninsystemet $i$ hjernen og oppstår i hovedsak ved kombinasjon av flere legemidler som øker serotoninnivået, som serotoninreopptakshemmere (SSRI), trisykliske antidepressiver(TCA), monoaminoksidasehemmere (MAO-hemmere), enkelte opioider og noen sentralstimulerende rusmidler (6). Antikolinergt syndrom forårsakes av for sterk blokkering av acetylkolin, som ved overdosering av legemidler eller forgiftninger (7).

Antipsykotika har også ekstrapyramidale bivirkninger i form av parkinsonisme, akutt dystoni, tremor, akatisi og tardive dyskinesier som kan være vanskelig å skille fra symptomene ved malignt nevroleptikasyndrom (4).

Malign hypertermi er en sjelden genetisk sykdom og har et mer akutt forløp (tab 2) (8).

På den sjette dagen, to dager etter overflyttingen, var pasienten fortsatt febril med temperatur opp mot $40^{\circ} \mathrm{C}$. Det var tilkommet elektrolyttforstyrrelser i form av hypokalemi og hypernatremi. Antall leukocytter var normalisert, men kreatinkinase var stigende (tab 1). Pasienten var sirkulatorisk stabil, men hyperventilerte med en kompensert metabolsk acidose. De diagnostiske kriteriene for malignt nevroleptikasyndrom var oppfylt, med alvorlig muskelrigiditet, forhøyet temperatur, dysfagi, endret bevissthet, mutisme, takykardi, hypertensjon, leukocytose og forhøyet kreatinkinase. Pasienten fikk symptomatisk behandling med væske, korrigering av forstyrrelser i elektrolytter og syrebasestatus og forebyggende tiltak mot trombose, liggesår og kontrakturer.

Dag syv ble pasienten flyttet til medisinsk overvåkningsavdeling. Da han ikke var blitt bedre, valgte man å gi dantrolen $175 \mathrm{mg}$ intravenøst og bromokriptin $20 \mathrm{mg}$ som døgndose. Man forsøkte også avkjøling med isposer med varierende effekt. Pasienten var våken, men preget av uttalt rigiditet og dysfagi, og han kunne ikke snakke. Det ble startet med parenteral ernæring da pasienten ikke klarte å spise. Dag ti falt temperaturen til $38^{\circ} \mathrm{C}$, men kreatinkinaseverdiene fortsatte å stige. Han hadde fremdeles betydelig acidose og hypokalemi (tab 1). Pasienten utviklet diaré og CRP-stigning. Grunnet mistanke om bakteriell infeksjon med ukjent fokus, ble det startet intravenøs antibiotikabehandling med cefuroksim og metronidazol. Pasienten fikk også oxazepam 60-80 mg døgndose som behandling av forvirring og rigiditet.

Malignt nevroleptikasyndrom krever, med unntak av tilfeller med milde symptomer, innleggelse og behandling i medisinsk overvåkningsavdeling (5). Antipsykotika, samt eventuelt andre dopaminantagonister og litium, skal seponeres umiddelbart. Vitale parametere skal overvåkes og symptomatisk behandling gis. Dersom kreatinkinaseverdien er betydelig forhøyet, kan det tilsi utvikling av rabdomyolyse og gjøre det nødvendig å forebygge nyresvikt. Benzodiazepiner kan ha en gunstig effekt gjennom å hemme basalgangliene og motorisk korteks.

Ved alvorlig tilstand og med kroppstemperatur opptil $39,5^{\circ} \mathrm{C}$ kan malignt nevroleptikasyndrom behandles med $15 \mathrm{mg}$ bromokriptin, en dopaminagonist, per døgn. Man går ut fra at dopaminblokade kan redusere symptomene. Dersom pasienten ikke er i stand til å innta perorale medikamenter, eller temperaturen stiger over $39,5^{\circ} \mathrm{C}$, skal man behandle med dantrolen intravenøst. Ved oppstart av dantrolen administreres $2 \mathrm{mg}$ per
RAMME 1

Differensialdiagnoser malignt

nevroleptikasyndrom (5)

Psykiatriske/nevrologiske tilstander:

Malign katatoni

Delirium

Status epilepticus

Toksiske/farmakologiske tilstander:

Serotonergt syndrom

Antikolinergt syndrom

Intoksikasjon sentralstimulerende

rusmidler/medikamenter

Malign hypertermi

Litiumintoksikasjon

Abstinens

Infeksiøse tilstander:

Encefalitt

Meningitt

Sepsis

Endokrine tilstander:

Tyreotoksikose

kg kroppsvekt, maks 10 mg per kg. Dantrolen er en kalsiumantagonist som kan gi redusert muskelkontraksjon $(5,9)$.

Ut fra manglende bedring med medikamentell behandling ble det besluttet å forsøke elektrokonvulsiv terapi (ECT). Den 14. dagen etter innleggelse mottok pasienten sin første elektrokonvulsive terapibehandling, i form av unilateral høyresidig stimulering. Totalt ble det gitt ti slike behandlinger over tre uker. Behandlingene ble vurdert som teknisk tilfredsstillende og ukompliserte.

Hvis medikamentell behandling ikke har effekt, kan elektrokonvulsiv terapi være livreddende. Effekten av elektrokonvulsiv terapi ved malignt nevroleptikasyndrom er gjentatte ganger beskrevet i litteraturen. Men behandlingen er ikke ufarlig og har utløst hjerteflimmer og hjertestans (2). Suksametonium, som vanligvis gis som muskelrelakserende medikament ved elektrokonvulsiv terapi, blir vurdert som kontraindisert (9) ved malignt nevroleptikasyndrom.

Tabell 1 Utvalgte laboratorieprøver

\begin{tabular}{|c|c|c|c|c|c|c|c|c|c|c|c|c|c|c|c|c|c|c|}
\hline & $\begin{array}{c}\text { Dag } \\
1\end{array}$ & $\begin{array}{c}\text { Dag } \\
5\end{array}$ & $\begin{array}{c}\text { Dag } \\
7\end{array}$ & $\begin{array}{c}\text { Dag } \\
8\end{array}$ & $\begin{array}{c}\text { Dag } \\
9\end{array}$ & $\begin{array}{c}\text { Dag } \\
10\end{array}$ & $\begin{array}{c}\text { Dag } \\
12\end{array}$ & $\begin{array}{c}\text { Dag } \\
13\end{array}$ & $\begin{array}{l}\text { Dag } \\
14\end{array}$ & $\begin{array}{l}\text { Dag } \\
15\end{array}$ & $\begin{array}{l}\text { Dag } \\
16\end{array}$ & $\begin{array}{l}\text { Dag } \\
17\end{array}$ & $\begin{array}{c}\text { Dag } \\
19\end{array}$ & $\begin{array}{l}\text { Dag } \\
21\end{array}$ & $\begin{array}{c}\text { Dag } \\
25\end{array}$ & $\begin{array}{l}\text { Dag } \\
31\end{array}$ & $\begin{array}{l}\text { Dag } \\
35\end{array}$ & $\begin{array}{c}\text { Dag } \\
40\end{array}$ \\
\hline $\begin{array}{l}\text { Leukocytter } \\
\left(3,5-10,0 \cdot 10^{9} / 1\right)\end{array}$ & 12,8 & 16,7 & 10,9 & 9,4 & 12,6 & 13,9 & 13,4 & 15,0 & 16,7 & 15 & 11,7 & 14,9 & 15,8 & 11,6 & 8,3 & 6,4 & & 10,5 \\
\hline CK $(40-280 / U / L)$ & & 778 & 686 & 857 & 1474 & 2102 & 2261 & 2408 & 1814 & & 1840 & 3032 & 495 & 143 & 43 & 35 & 33 & \\
\hline
\end{tabular}


Tabell 2 Symptomer og funn ved malign katatoni, antikolinergt syndrom, malignt nevroleptikasyndrom, serotonergt syndrom og malign hypertermi $(1-7)++=$ vanlig symptom, $+=$ symptom varierende til stede, +/- = symptom sjelden til stede

\section{Symptomer/funn}

Malign

katatoni

\section{Antikolinergt} syndrom Malignt nevro-
leptikasyndrom
Malign hypertermi

\section{Generelle}

Redusert allmenntilstand

\section{Autonome}

Hypertermi

Svetting

Urininkontinens/retensjon

Diaré/obstipasjon

Kvalme/oppkast

Takykardi

Forhøyet/ustabilt blodtrykk

Varm tørr hud/tørre slimhinner/cyanose

\section{Motoriske}

Muskelrigiditet

Tremor

Dysfagi

Motorisk uro

$++$

bisarre kroppsholdninger

Hyperrefleksi/myoklonus

\section{Sensoriske}

Tegn til muskelskade/smerter

Hodepine

\section{Kognitive}

Konfusjon

Fluktuerende bevissthetsnivå

Stupor

Koma

\section{Psykiske}

Hallusinasjoner

Angst/agitasjon

Mutisme

\section{Laboratoriemessige}

Leukocytose

Forhøyet kreatinkinase (CK)

$\begin{array}{ccccc} & ++ & ++ & + \\ & ++ & ++ & \\ ++ & ++ & ++ & \\ ++ & +/- & & \\ & +/- & & & \\ & ++ & & ++ \\ & ++ & & ++ \\ & & & ++\end{array}$

$\begin{array}{ccccc}++ & ++ & ++ & ++ \\ & ++ & ++ & ++ \\ & ++ & +- & \\ ++ & & + & \\ & & +/- & \end{array}$

++

$++$

$+1-$

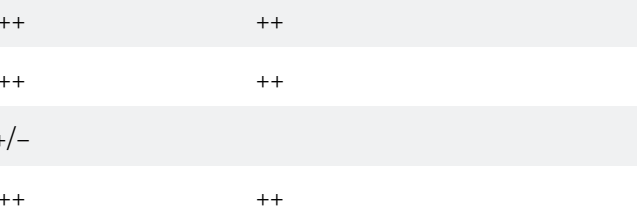


Tre dager etter første behandling (dag 17) sank pasientens temperatur under $38^{\circ} \mathrm{C}$ for første gang siden innleggelsen. Etter den andre behandlingen fremkom en klinisk bedring, hvor han var mer våken og kunne kommunisere med enstavelsesord. Bromokriptin ble redusert til $15 \mathrm{mg}$ døgndose.

I løpet av de neste to ukene avtok muskelrigiditeten gradvis. Pasienten kommuniserte bedre, var afebril, og nivået på elektrolyttene normaliserte seg. Svelgfunksjonen bedret seg, og han begynte å ta til seg peroral næring. Fire uker etter innkomst ble pasienten flyttet tilbake til psykiatrisk avdeling.

Malignt nevroleptikasyndrom er ikke en absolutt kontraindikasjon for behandling med antipsykotika, men det er viktig at pasienten er symptomfri i minst to uker før oppstart. Bytte av medikament, lav startdose og langsom opptrapping til lavest effektive dose er nødvendig, sammen med monitorering av vitale parametere og muskelrigiditet for å avdekke et eventuelt residiv. Dessuten bør depotinjeksjoner unngås (2). Risikoen for residiv av malignt nevroleptikasyndrom angis å være 30-50\% (10).

Ut fra et farmakodynamisk perspektiv på dopamin D2-blokade er quetiapin og klozapin forsvarlig å starte opp med (11). Begge legemidlene har et potensial for vektøkning $(12,13)$ og vil være ugunstige hos pasienter med diabetes mellitus. Klozapin kan initialt gi forbigående feber og takykardi, hvor malignt nevroleptikasyndrom må vurderes (12).

Siden pasienten hadde kjent diabetes mellitus og kardiovaskulær sykdom ble, etter gjennomgang av relevant litteratur og diskusjon med farmakolog ved regionssykehus, quetiapin valgt $(14,15)$. Pasienten hadde da vært symptomfri $i$ to uker, og serumkonsentrasjonen av risperidon var $i$ samme periode null. Pasienten ble vurdert til å være i god form og samtykket til videre medikamentell behandling. Det ble startet opp med quetiapin $12,5 \mathrm{mg}$ per os. Ved utskrivning 11 uker etter oppstart var dosen $600 \mathrm{mg}$. Det ble ikke observert åpenbare bivirkninger avmedikamentet, hellerikke residiv av malignt nevroleptikasyndrom.

Etter at han ble frisk fortalte pasienten at han husket mye av det som hadde skjedd under sykehusoppholdet, og at han opplevde spesielt god effekt av elektrokonvulsiv terapi. 19 uker etter innkomst ble han utskrevet til et korttidsopphold ved et lokalt sykehjem.

\section{Diskusjon}

Diagnostisering av malignt nevroleptikasyndrom er utfordrende da pasientene har symptomer som er vanlige ved mange medisinske problemstillinger, som heteslag, alvorlige hjerneinfeksjoner, sepsis, delirium, toksiske encefalopatier og status epilepticus (ramme 1)
(5). Hos denne pasienten var malign katatoni en nærliggende differensialdiagnose, men uttalt feber, rigiditet og svetting pekte mer i retning av malignt nevroleptikasyndrom (16).

Malignt nevroleptikasyndrom oppstår som oftest i løpet av de to første ukene etter påbegynt behandling eller doseøkning, men kan også forekomme senere (5). Patofysiologien er ikke fullstendig forstått, men redusert dopaminerg aktivitet forårsaket av blokade av dopamin 2 (D2)-reseptorer antas å være av klar betydning (5). Risikofaktorer er redusert allmenntilstand, rask doseøkning av antipsykotika, dehydrering, tidligere episoder med malignt nevroleptikasyndrom intramuskulære antipsykotikainjeksjoner, lav serumkonsentrasjon av jern, traume, samtidig behandling med litium, antikolinerge medikamenter eller antidepressiver. Dessuten ses familiær opphopning, slik at en genetisk komponent er sannsynlig (5). Førstegenerasjons antipsykotika som haloperidol er vanligste årsaker (5). I litteraturen finnes kun to tilfeller av malignt nevroleptikasyndrom ved bruk av risperidon depotinjeksjon, men begge tilfellene skjedde kort tid etter oppstart, og pasienten hadde fått et førstegenerasjons antipsykotika i tillegg $(17,18)$.

Vår pasient utviklet malignt nevroleptikasyndrom etter å ha brukt samme dose risperidon i ti år.

Eliminering av depotinjeksjoner tar lengre tid enn perorale preparater og kan gi forverring av malignt nevroleptikasyndrom $i$ lang tid etter at siste dose er administrert. Vår kasuistikk understreker viktigheten av en helhetlig tilnærming $\mathrm{i}$ arbeidet med pasienter med psykiatriske lidelser.

Pasienten har gitt samtykke til at artikkelen blir publisert.

\section{Hanne Indermo Solhaug (f. 1981)}

er spesialist i psykiatri.

Forfatter har fylt ut ICMJE-skjemaet og oppgir ingen interessekonflikter.

\section{Rosalie Broekhof (f. 1984)}

er spesialist i psykiatri.

Forfatter har fylt ut ICMJE-skjemaet og oppgir ingen interessekonflikter.

\section{Kari Bruheim (f. 1973)}

er spesialist i anestesiologi og lege i spesialisering i psykiatri.

Forfatter har fylt ut ICMJE-skjemaet og oppgir ingen interessekonflikter.

\section{Sara Germans Selvik (f. 1972)}

er spesialist i psykiatri. Hun er også styremed lem av Nasjonalt forum for akuttpsykiatri (NFAP), leder av referansegruppe for Nasjonal kompetansetjeneste for personlighetspsykiatri (NAPP) og førsteamanuensis ved Norges teknisk-naturvitenskapelig universitet.

Forfatter har fylt ut ICMJE-skjemaet og oppgir ingen interessekonflikter.

\section{Mathis Heibert (f. 1972)}

er spesialist i indremedisin og fordøyelsessykdommer

Forfatter har fylt ut ICMJE-skjemaet og oppgir ingen interessekonflikter.

Litteratur

1. Daniels J. Catatonia: clinical aspects and neurobiological correlates. J Neuropsychiatry Clin Neurosci 2009; 21: 371-80.

2. Van Den Broek WW, Moleman P. Anxiolytica en hypnotica. I: Moleman P, red. Praktische psychofarmacologie. 3. utgave. Houten/Diegem: Bohn Stafleu Van Loghum, 1998: 9.

3. Taylor MA, Fink M. Catatonia in psychiatric classification: a home of its own. Am J Psychiatry 2003. 160: 1233-41

4. Sadock BJ, Sadock VA. red. Comprehensive textbook of psychiatry. 7. utgave. Philadelphia, PA: Lippincott Williams \& Wilkins, 2000: 680

5. Berman BD. Neuroleptic malignant syndrome: a review for neurohospitalists. Neurohospitalist $2011 ; 1: 41-7$

6. Spigset 0. Serotonergt syndrom - en særegen legemiddelbivirkning. Norsk Farmaceutisk Tidsskrift 2010; 3: 11-3

7. Sadock BJ, Sadock VA. red. Comprehensive textbook of psychiatry. 9. utgave. Philadelphia, PA: Lippincott Williams \& Wilkins, 2009: 3017

8. Gurrera RJ. Is neuroleptic malignant syndrome a neurogenic form of malignant hyperthermia? Clin Neuropharmacol 2002; 25: 183-93.

9. ALNSF. http://anestesi.no/farmakologi/ intravenos/123-muskelrelaksering (28.9.2015).

10. González-Blanco L, García-Prada H, Santamarina $S$ et al. Recurrence of neuroleptic malignant syndrome. Actas Esp Psiquiatr 2013; 41: 314-8.

11. Wells BG, DiPiro JT, Schwinghammer TL et al, red. Pharmacotherapy handbook. 7. utgave. 2008: 1110.

12. Statens legemiddelverk. Preparatomtale (SPC) Leponex. Sist endret 14.7.2015. https://www.legemiddelsok.no/sider/default aspx?searchquery=leponex\&f=Han;Mtl;Vir;ATC Var:Mar:Mid:Avr:gen:par:\&pane=0 (5.4.2017).

13. Statens legemiddelverk. Preparatomtale (SPC) Seroquel. Sist endret 25.8.2015. https://www.legemiddelsok.no/sider/default.aspx? searchquery=Seroquel\&f=Han;Mtl;Vir;ATC;Var Mar:Mid;Avr;gen;par; \& pane=0 (5.4.2017)

14. RELIS. Hvilket antipsykotikum har lavest risiko for å gi gjentatt malignt antipsykotikasyndrom? http://relis.arnett.no/Utredning_Ekstern.aspx? Relis $=6 \& S=281 \& R=X(5.4 .2017)$.

15. RELIS. Valg av antipsykotikum etter malignt nevroleptikasyndrom. http://relis.arnett.no/Utredning_ Ekstern.aspx?Relis=5\&S=3887\&R=X (5.4.2017).

16. Lang FU, Lang $S$, Becker T et al. Neuroleptic malignant syndrome or catatonia? Trying to solve the catatonic dilemma. Psychopharmacology (Berl) 2015; 232: 1-5

17. Mall GD, Hake L, Benjamin AB et al. Catatonia and mild neuroleptic malignant syndrome after initiation of long-acting injectable risperidone: case report. J Clin Psychopharmacol 2008; 28: 572-3.

18. Yamashita T, Fujii Y, Misawa F. Neuroleptic malig nant syndrome associated with risperidone longacting injection: a case report. J Clin Psychopharmacol 2013: 33: 127-9. 